\title{
The water chemistry of some shallow lakes in Northern Patagonia and their nitrogen status in comparison with remote lakes in different regions of the globe
}

\author{
Michela ROGORA*, Julieta MASSAFERRO ${ }^{1)}$, Aldo MARCHETTO, Gabriele TARTARI and Rosario MOSELLO \\ CNR Institute of Ecosystem Study, L.go V. Tonolli 50, 28922 Verbania Pallanza, Italy \\ ${ }^{1)}$ INIBIOMA/CONICET, 8400, Bariloche, Argentina \\ *e-mail corresponding author: m.rogora@ise.cnr.it
}

\begin{abstract}
Eighteen small shallow lakes located in the Northern Patagonian Lake District, in southern South America, were sampled in 2001 and analysed for the main chemical variables ( $\mathrm{pH}$, conductivity, alkalinity, major ions and nutrients). The study lakes span a wide geographical and altitudinal range and belong partly to the Pacific and partly to the Atlantic watershed. The main aim of this study was to investigate the relationships between water chemistry and physical/geographical properties of these lakes. Secondly, the nitrogen content of the lakes was considered in detail, and results compared to those obtained in previous studies carried out in other remote areas of the globe (the Central Southern Alps in Italy, the Sierra da Estrela region in Portugal, the Svalbard Islands in the Arctic, the Khumbu-Himal region in Nepal, and the Terra Nova Bay area in Antarctica). In the Alps, lakes are characterised by markedly high nitrogen concentrations, manly as nitrate, due to the high inputs of nitrogen compounds from downwind sources like the Po Plain in Northern Italy. Conversely, lakes at remote locations such as the Andes, Antarctica and Himalaya are characterised by a low nitrogen content, mainly as organic nitrogen. This status is related to the limited atmospheric inputs of nitrogen affecting these regions.
\end{abstract}

Key-words: nitrate, atmospheric deposition, Alps, Nepal, Antarctica.

\section{INTRODUCTION}

Atmospheric pollution and anthropogenic activities in general can alter the cycles of natural elements in both terrestrial and aquatic ecosystems. In particular, the deposition of atmospheric pollutants such as acidifying compounds, organic pollutants and heavy metals may affect also areas located distant from the main emission sources. Remote lakes, defined as those at high altitude in mountain areas or at high latitude in the Arctic regions, by virtue of their distance from any human activities, are generally considered to be pristine systems. Nevertheless, they have proved to be affected by long-range atmospheric pollution (e.g., Rose 1995; Carrera et al. 2002; Heit et al. 2004) and by the effect of climate change (Battarbee et al. 2002; Catalan et al. 2002; Smol et al. 2005). Hence, remote lakes are considered "early response" indicators of climate change, atmospheric deposition and air pollutants. Consequently, a number of studies on remote lakes in different regions of the globe have been performed with the aim to describe their water chemistry and biota (e.g., Macek et al. 2006; Llames \& Vinocur 2007; Diaz et al. 2007; Kumke et al. 2007), and to evaluate their sensitiveness towards anthropogenic stressors like water exploitation, land use change, tourism and recreational use (Mc Garrigle \& Champ 1999), pollutant deposition (Allan 1999; Wolfe et al. 2001), and, more recently, climate change (Filippelli et al. 2006; Sommaruga 2007).
Long-term monitoring programmes about the effects of atmospheric pollution, for instance, showed how the water chemistry of remote lakes in mountain regions of both Europe and North America is affected by the deposition of long-range transported nitrogen $(\mathrm{N})$ compounds. As an example, lakes in the Southern Central Alps of Europe are characterised by high $\mathrm{N}$ concentration, mainly nitric N (Psenner et al. 2000; Curtis et al. 2005), due to the high level of $\mathrm{N}$ deposition (between 15 and $25 \mathrm{~kg} \mathrm{~N}^{-1} \mathrm{y}^{-1}$ ). Also in the Colorado Front Range, in North America, even moderate $\mathrm{N}$ deposition (3-5 $\mathrm{kg} \mathrm{N} \mathrm{ha}^{-1} \mathrm{y}^{-1}$ ) induced recent increases in surface water $\mathrm{NO}_{3}$ concentrations and rapid ecological changes in alpine lakes (Baron \& Caine 2000; Wolfe et al. 2001). On the other hand, nitrate $\left(\mathrm{NO}_{3}\right)$ concentrations are usually below the detection limit in lakes and streams subject to low $\mathrm{N}$ input $(<1 \mathrm{~kg}$ $\left.\mathrm{N} \mathrm{ha}{ }^{-1} \mathrm{y}^{-1}\right)$ and organic nitrogen (ON) accounts for a substantial proportion of the total nitrogen (TN) content (Hedin et al. 1995; Kaushal \& Lewis 2003).

In this paper we focused on the Northern Patagonian Lake District, in southern South America, showing the results of a sampling campaign performed in 2001 on 18 shallow lakes spanning a wide geographical and altitudinal range. Some of these lakes have been already sampled and analysed for the main chemical variables in previous studies (Pedrozo et al. 1993; Soto et al. 1994; Pedrozo \& Chillrud 1998; Zagarese et al. 2000), but here only new data are shown. 
The main aim of the present study was to explore the relationships between water chemistry and physi$\mathrm{cal} /$ geographical properties of the lakes and to provide additional information about these freshwater ecosystems. Our findings were compared and discussed in relation to those obtained in previous studies performed in the same area. In a second section of the paper, the $\mathrm{N}$ status of the study lakes was compared to those of other lakes located in remote regions of the globe, such as the Central Southern Alps in Italy, the Sierra da Estrela region in Portugal, the Svalbard Islands in the Arctic, the Khumbu-Himal region in Nepal, and the Terra Nova Bay area in Antarctica.

\section{LIMNOLOGICAL STUDIES IN THE NORTHERN PATAGONIAN LAKE DISTRICT}

There is a good record of limnological studies in the Northern Patagonian Lake district. Pioneer studies in Southern South America were carried out by Thomasson $(1959,1963)$, who studied the water chemistry and plankton composition of several lakes in Chile and Argentina. Thomasson named Araucarian lakes those located between $39^{\circ}$ and $43^{\circ} \mathrm{S}$, eastern and western of the Cordillera de los Andes, along the Chilean and the Argentinean side. Successively, Campos and co-authors (see Campos 1984, and reference cited) reported for the first time morphometric, chemical, physical and biological aspects of the Chilean lakes. In Argentina, Quirós (1988, 1991), and Drago \& Quirós (1995), studied physical and morphometric aspects of several Patagonian lakes. These extensive work showed very heterogeneous conclusions related to climate, morphology and edaphic conditions in the area.

Pedrozo et al. (1993) described the chemical composition of 20 rivers and 30 lakes of northern Patagonia, mainly focusing on the importance of nutrients, both $\mathrm{N}$ and $\mathrm{P}$, in algal growth limitation. More recently, an overview of the environmental status of the Argentinean lakes was presented by Quirós \& Drago (1999). They concluded that Argentina still has a larger proportion of lake waters in natural conditions but that future developments for natural resources may pose a threat to natural lake environments. Modenutti et al. (1998) also pointed out how the increasing human activity in the last few years will have important future effects on the communities of Patagonian lakes.

Balseiro and Modenutti have a large record of limnological studies in North Patagonia, ranging from food web dynamics (e.g., Balseiro et al. 1997, 2001; Modenutti et al. 2003) to photosynthetic activity (Modenutti et al. 2004; Perez et al. 2007) in the lakes located in the Nahuel Huapi National Park.

Morris et al. (1995) produced a comparative studies between Patagonian lakes and lakes in various regions of the Northern Hemisphere, considering both chemical charateristics and optical properties of lake water.
Recently, a special Issue of the journal Limnologica collated a number of papers on limnological studies in temperate South America, both from the western and the eastern Andean side (Woelfl 2007). Among them, Diaz et al. (2007) presented an analysis of the chemical composition and the trophic state of 39 Patagonian lakes, 8 of which are in common with the present study. The authors mainly focused on the comparison between measured chlorophyll- $a$ concentrations and chlorophyllcarrying capacities of the nutrients and pointed to a nitrogen deficiency of the lakes as to the main factor explaining their oligotrophic conditions (Diaz et al. 2007).

A further contribution to the discussion on nutrient limitation in the Andean-Patagonian lakes was provided by Callieri et al. (2007), showing the relevant role of phosphorus in the limitation of primary production in deep, ultraoligothrophic lakes.

Natural and artificial lakes in northern Patagonia (Argentina and Chile) are also considered very important from the paleoecological and paleoclimatological point of view. This kind of studies is an important complement in limnological studies as they contribute to the global understanding of lake dynamics. These mid-latitude regions of South America are indeed highly sensitive to climatic changes, as suggested by paleoecological data (Massaferro \& Vandergoes 2007). The El Niño Southern Oscillation (ENSO), volcanism and anthropogenic events have also a significant impact in the physical and chemical properties of the aquatic systems, as well as in the vegetation patterns (Paruelo et al. 1998).

Paleolimnology in Argentina and Chile achieved greater importance during the last 10 years. The first studies were developed in PROGEBA, a Quaternary programme from CONICET that congregated a multidisciplinary team of geologists and biologists in northern Patagonia. Since then, an increasing number of publications about past climate and ecological changes in lakes were developed in the area of the Nahuel Huapi National Park (e.g., Fernandez 1994; Ariztegui et al. 1998; Massaferro et al. 1999).

\section{STUDIED AREA, METHODS AND SOURCE OF THE DATA}

\subsection{Characteristics of the studied lakes}

The studied lakes are located mainly within the Nahuel Huapi National Park (NHNP) in Patagonia, Argentina, which covers $7100 \mathrm{~km}^{2}$. A few lakes belong to Lago Puelo National Park, located south of NHNP. Almost all the studied lakes are located in Argentina except two of them (Laguna Los Patos and Laguna Gallinas) which belong to the Chilean lake district (Fig. 1). Lakes belong to both Atlantic and Pacific watersheds (Tab. 1).

The main limnological features of the lakes are shown in table 1 , together with water chemistry data. 


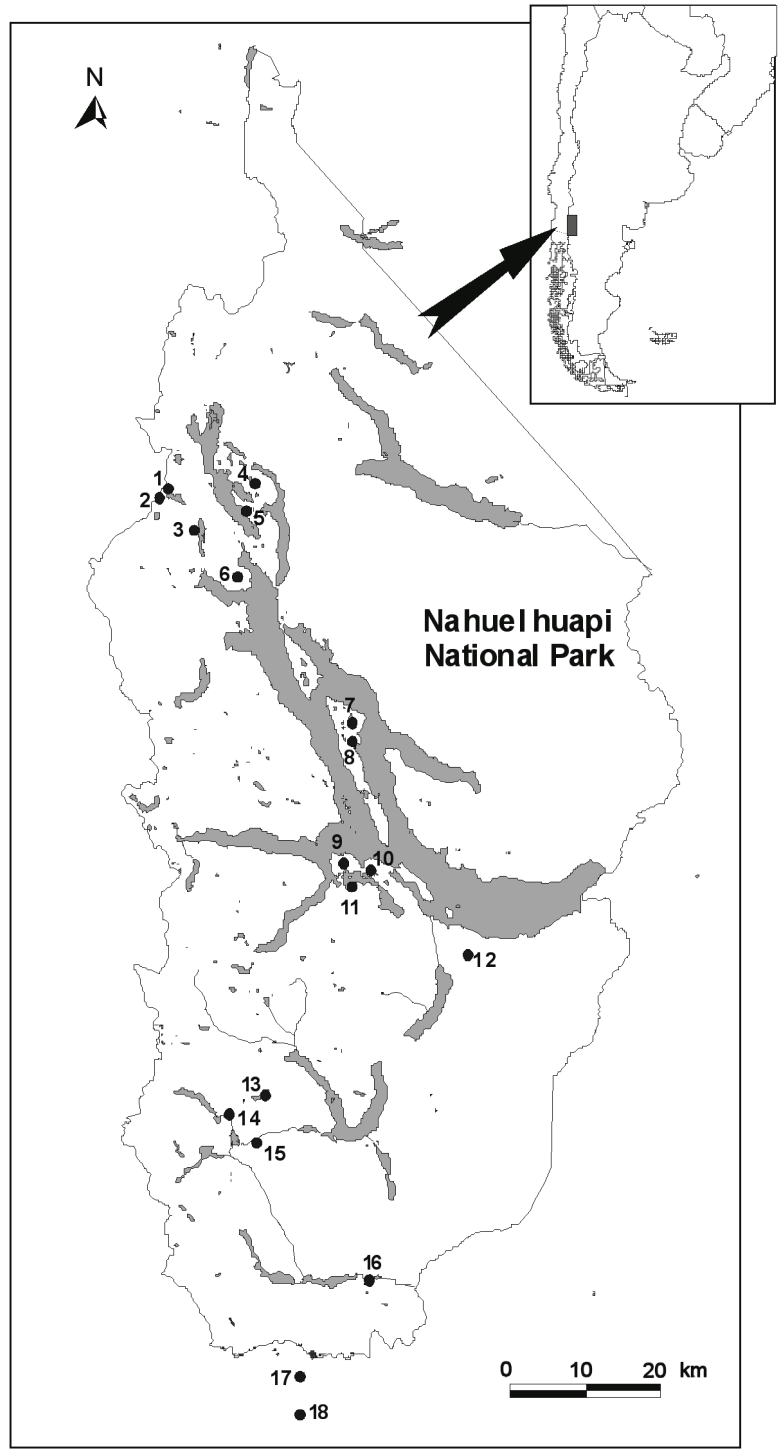

Fig. 1. Map showing the location of the study lakes (numbers refer to table 1 ).

Lakes lie between 680 and $1000 \mathrm{~m}$ a.s.l. except Lake Verde (1466 m a.s.1.) which is also the shallowest one (1.5 $\mathrm{m}$ depth). In the other lakes water depth varies between 7 and $32 \mathrm{~m}$ (Tab. 1). The majority of these aquatic environments are of glacial origin. A few of them are formed by the damming effect of the frontal moraines left behind by retreating glaciers. Despite the Cordillera de los Andes acting as a geographical barrier, lakes in both Argentinean and Chilean territories have similar chemical characteristics. Lake water chemistry is controlled by silicate and bicarbonate reactions with low nutrient concentrations, especially phosphorus (Soto et al. 1994; Diaz et al. 2007). The input of nutrients to these lakes depends on the chemical composition of soil drainage and rainfall (Campos 1984). In general, all of these freshwater bodies are ultraoligotrophic/oligotrophic and warm monomictic with thermal

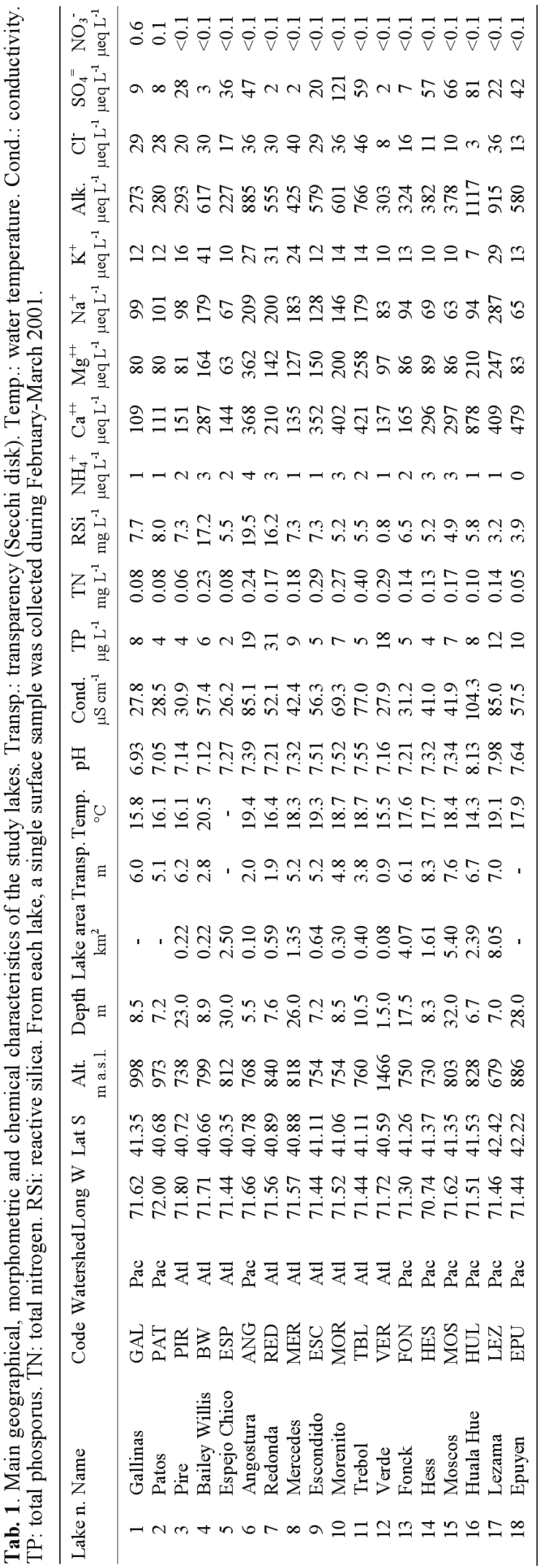


stratification in summer (Quiros \& Drago 1999). However, the smallest ones could be dimictic or cold polymictic.

\subsection{Geology, climate and vegetation}

The geology of the area is dominated by igneous, volcanic and plutonic rocks formed by glaciers during the Pleistocene. Sedimentary and metamorphic rocks are of secondary importance. Volcanic eruptions occurred during the Quaternary have been relevant in this region generating the parental material of Andean soils. The "Circumpacific volcanic zone", between 38 and $44^{\circ} \mathrm{S}$ in Chile, is responsible of the volcanic deposition in this area, affecting both the Chilean and the Argentinean side. Valleys are dominated by glacial drift and alluvial deposits (Markert et al. 1997).

The climate of the region can be classified as moderately continental, ranging from cold temperate near the Andes to arid and warmer on the Patagonian Plateau. Almost all the Patagonian region is dominated by air masses coming from the Pacific Ocean and strong constant west-winds (westerlies) are dominant across the region. These winds are present all the year round; mean annual speed values in this area oscillates between 15 and $22 \mathrm{~km} \mathrm{~h}^{-1}$.

The Andes plays a crucial role in determining the climate of Patagonia acting as a barrier for humid air masses coming from the Pacific Ocean. This results in high precipitation amount in the Chilean side (annual rainfall exceeding $2000 \mathrm{~mm}$ ). Crossing the Andes, in Argentina, precipitation decreases exponentially eastwards. (Paruelo et al. 1998). The strong west-east precipitation gradient varies from $>2000 \mathrm{~mm} \mathrm{y}^{-1}$ (Argentina/Chilean border) to $500 \mathrm{~mm} \mathrm{y}^{-1}$ (Lake Nahuel Huapi meteorological station). Mean annual air temperatures in the Nahuel Huapi National park is $8{ }^{\circ} \mathrm{C}$ with a maximum average summer temperature of $14{ }^{\circ} \mathrm{C}$ and a minimum average winter temperature of $2{ }^{\circ} \mathrm{C}$. These climate gradients impose different structural patterns of soils and vegetation as well as different patterns of ecosystems functioning such as soil water dynamic and nutrient cycling. In fact, the vegetation of this part of Patagonia is an ecotonal belt containing temperate rainforest vegetation mixed with steppe elements towards the east steppe border.

Temperate rainforests are the dominant native vegetation showing a vegetation pattern with a particular richness. Modern forest communities are represented by Valdivian, North Patagonian and subantarctic elements lying on Andisols or volcanic soils (1000-3000 $\mathrm{mm}$ rainfall). The most characteristic plant communities encompas several species of Nothofagus and the conifers Austrocedrus chilensis and Fitzroya cupresoides; the undergrowth cover is dominated by bamboo-like canes (Chusquea sp.) and shrubs (Berberis sp.).

\subsection{Sampling, analysis and data elaboration}

The fieldtrip in North Patagonia was carried out during February and March 2001. Eighteen lakes were sampled for water chemistry. They have similar morphometric characteristics (except Lake Epuyen and Lake Lezama, see table 1). The lakes were chosen along a latitudinal gradient and equally representing the Pacific and the Atlantic watershed (Fig. 1, Tab. 1). All the sampled lakes were small (lake area between 0.2 and $8 \mathrm{~km}^{2}$ ) and shallow (depth always $<35 \mathrm{~m}$ ). From each lake, a single surface sample was collected in a prewashed plastic bottle and stored at $4{ }^{\circ} \mathrm{C}$ for successive chemical analysis. Measurements such as transparency, $\mathrm{pH}$, oxygen concentration, conductivity, temperature and GPS were completed in situ.

Chemical analysis of water samples were performed in the chemical laboratory of the Institute of Ecosystem Study of the National Research Council of Italy (CNR ISE). Lake samples were analysed for the main chemical variables: $\mathrm{pH}$, conductivity, alkalinity (acidimetric titration, Gran's method), ammonium, total nitrogen, total phosphorus and reactive silica (spectrophotometry), major anions $\left(\mathrm{SO}_{4}{ }^{-}, \mathrm{NO}_{3}{ }^{-}, \mathrm{Cl}^{-}\right)$and cations $\left(\mathrm{Ca}^{++}\right.$, $\mathrm{Mg}^{++}, \mathrm{Na}^{+}, \mathrm{K}^{+}$) (ion chromatography). ON concentrations were calculated from the difference between $\mathrm{TN}$ and inorganic $\mathrm{N}\left(\mathrm{IN}=\mathrm{N}^{-\mathrm{NO}_{3}}+\mathrm{N}-\mathrm{NH}_{4}\right)$ concentrations. Details on the analytical methods used can be found in Tartari \& Mosello (1997).

To check analytical quality for each analysis, a comparison between the sum of anions and cations, and between measured and calculated conductivity was performed. Further quality assurance measures involved the use of control charts and the analysis of synthetic samples on a regular basis. Participation in several interlaboratory comparisons on surface water analysis allowed a further quality check of the results (Marchetto et al. 1999).

Correlation analysis was performed to find out eventual relationships between geographical/physical attributes and chemical characteristics of the lakes. A cluster analysis (Ward's method, Euclidean distance) was used to identify the main groups of lakes according to water chemistry (14 variables, including nutrients and major ions). All statistical analyses were performed with S-plus 2000 (Math Soft).

\subsection{Remote lake datasets}

The concentrations of $\mathrm{N}$ compounds in Patagonian lakes were compared with those available for lakes in selected remote areas of Europe, in the Himalaya and in Antarctica. Data were collected during a number of limnological surveys performed by the researchers of CNR ISE in the framework of various research programmes. Part of the chemical data of these lakes have been published elsewhere, but an extensive evaluation of their $\mathrm{N}$ content is presented here for the fist time. The datasets are as follows. 
1) Central Alps: 35 lakes located in the Piedmont region, in the Ossola and Sesia Valleys, at an altitude between 1900 and $2700 \mathrm{~m}$ a.s.l., were sampled in late summer-autumn of 2000 and 2001, within the EU Projects EMERGE (European Mountain lake Ecosystems: Regionalisation, diaGnostics \& socio-economic Evaluation) and RECOVER: 2010 (Predicting recovery in acidified freshwater by the year 2010 and beyond). The lake watersheds mainly consist of bare rocks, with vegetation generally confined to small areas of alpine meadow. Part of the chemical data for these lakes has been presented elsewhere (Rogora et al. 2003), mainly focusing on the ionic content and the lake acidification status.

2) Svalbard Islands: 3 lakes were sampled in 1999 during a limnological investigation, as part of the CNR POLARNET Strategic Programme. In the lake area tundra vegetation prevailed and permafrost was found throughout the area. Water chemistry data of Lake Kongressvatnet have been presented in Guilizzoni et al. (2006), while the results for the other lakes have not been published before.

3) Himalaya: 31 lakes in the Sagarmatha National Park, Khumbu-Himal region, Nepal, were sampled in different campaigns from 1991 to 1997. The lakes were located between 4530 and $5480 \mathrm{~m}$ a.s.l., close to the permanent snow-line (5600 $\mathrm{m}$ a.s.l.). They are mainly small lakes $\left(<0.05 \mathrm{~km}^{2}\right)$, located in moraine areas partly covered by shrubs and grassland. An extensive evaluation of watershed and lake characteristics and of chemical data is reported in Tartari et al. (1998).

4) Antarctica: a number of small lakes in the Terra Nova Bay, Victoria Land, were sampled during two expeditions (1988-89 and 1990-91) in the framework of the National Program of Research in Antarctica (Guilizzoni et al. 1992). The lakes were all located in a volcanic area, along the coast of the Ross Sea, in holocenic emerged beaches $(5 / 290 \mathrm{~m}$ a.s.l.) or in moraine depressions (-5/-70 $\mathrm{m}$ a.sl.). About $30 \%$ of the lakes were larger than $1 \mathrm{ha}$, the others having a surface area between 0.3-0.6 ha, and mean depth ranged between 1.5 and 2.5 $\mathrm{m}$ (Guilizzoni et al. 1992). Data reported here referred to 16 lakes sampled in 1991 and have never been published before.

5) Portugal: 16 lakes located in the Serra da Estrela were sampled in 1994-95 in order to investigate their water chemistry in relation to atmospheric inputs. The Serra de Estrela is located in the central part of Portugal, in a National Park bearing the same name. The lakes were all located above the local tree line, between 1500 and $1800 \mathrm{~m}$ a.s.l., on granitic bedrock with scarce and thin soil cover (Boavida \& Gliwicz 1996).

All chemical analyses of the lakes were performed in the CNR ISE laboratory with the same methods employed for the Patagonian lakes. Limnological campaigns at these remote locations span a quite long period of time, since the early 1990 s to recent years. Nevertheless, the comparability of chemical data in time was assured by regular analytical quality control and intercomparisons (e.g., Marchetto et al. 1999) and by paired analyses performed for about a year after any change in the analytical methods to detect possible systematic differences in the results.

\section{RESULTS AND DISCUSSION}

\subsection{Water chemistry of Patagonian lakes}

All the lakes are characterised by well-buffered water, with $\mathrm{pH}$ values between 6.9 and 8.1 , and alkalinity always above $200 \mu \mathrm{eq} \mathrm{L}^{-1}$. The ionic content varies

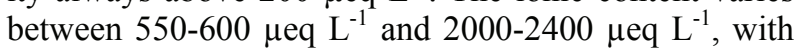
corresponding values of conductivity from 26-30 to 90$100 \mu \mathrm{S} \mathrm{cm}^{-1}$ at $20{ }^{\circ} \mathrm{C}$ (Tab. 1). As already pointed out in other studies on the water chemistry of Patagonian lakes (e.g., Pedrozo et al. 1993; Markert et al. 1997), the lakes are silica-dominated solutions, with calcium and bicarbonate as the prevailing ions. Calcium represents from 15 to $38 \%$ of the total ionic content, followed by $\mathrm{Na}^{+}$ and $\mathrm{Mg}^{++}$in similar proportion. Among anions, alkalinity represents about $40-45 \%$ of the total ionic content, while $\mathrm{SO}_{4}{ }^{=}$contributes for no more than $8 \%$. The $\mathrm{Na}^{+}$to $\mathrm{Cl}^{-}$ratio in lake water is between 4 and 8 in most of the lakes, highly above the ratio in marine water $(0.858)$, indicating a weathering contribution to $\mathrm{Na}^{+}$concentration. The contribution of atmospheric deposition to the $\mathrm{SO}_{4}{ }^{=}$content of the lakes can be excluded at this remote location. The $\mathrm{SO}_{4}{ }^{3}$ to $\mathrm{Cl}^{-}$ratio in lake water proved to be markedly higher than the corresponding ratio in seawater (0.103), with the exception of lakes Redonda and Mercedes (Tab. 1). As a consequence, the $\mathrm{SO}_{4}{ }^{=}$content in most of the lakes can be fully attributed to weathering of rocks and soils bearing sulphur minerals.

All the study lakes show quite high concentrations of reactive silica, between 3.0 and $8.0 \mathrm{mg} \mathrm{Si} \mathrm{L}^{-1}$ for most of the lakes. The only exception is Lake Verde, where the low RSi value can be explained by the high productivity of the lake. Very high concentrations (above $16 \mathrm{mg} \mathrm{Si} \mathrm{L}^{-1}$ ) are found in three lakes: Bailey Willis, Angostura and Redonda. The same lakes are also characterised by a high content of $\mathrm{Na}^{+}$and $\mathrm{K}^{+}$, suggesting that the weathering of secondary clay minerals, derived form $\mathrm{K}$ - or Na-feldspars, is of primary importance in these lake catchments.

Although northern Patagonian lakes have been previously classified as ultraoligotrophic and oligotrophic according to the low total phosphorus (TP) content (2$10 \mu \mathrm{g} \mathrm{P} \mathrm{L}^{-1}$ ) (Pedrozo et al. 1993; Market et al. 1997; Quirós \& Drago 1999; Balseiro et al. 2007), in this study some of them showed medium to high TP concentrations (12 to $30 \mu \mathrm{g} \mathrm{P} \mathrm{L}^{-1}$; Tab. 1). Lake Redonda and Angostura, showing the highest TP content, are located on the Victoria Island, in the Lake Nahuel Huapi, and in the urban area of the touristy village Villa La Angostura, respectively. It can be hypothesised that 
Tab. 2. Correlations (Pearson product-moment correlations) between geographical/physical and chemical attributes of the study lakes. Significant correlation $(p<0.05)$ are in bold.

\begin{tabular}{|c|c|c|c|c|c|c|c|c|c|c|c|c|c|}
\hline & Cond. & $\mathrm{TP}$ & $\mathrm{TN}$ & $\mathrm{RSi}$ & ON & $\mathrm{H}^{+}$ & $\mathrm{Ca}^{++}$ & $\mathrm{Mg}^{++}$ & $\mathrm{Na}^{+}$ & $\mathrm{K}^{+}$ & Alk. & $\mathrm{Cl}^{-}$ & $\mathrm{SO}_{4}{ }^{=}$ \\
\hline \multirow[t]{2}{*}{ Longitude } & -0.12 & 0.31 & -0.01 & 0.08 & 0.03 & 0.31 & -0.31 & 0.04 & 0.17 & 0.11 & -0.09 & 0.18 & -0.32 \\
\hline & p 0.69 & p 0.31 & p 0.97 & p 0.80 & p 0.91 & p 0.31 & p 0.30 & p 0.91 & p 0.59 & p 0.73 & p 0.76 & p 0.56 & p 0.29 \\
\hline \multirow[t]{2}{*}{ Latitude } & 0.39 & -0.14 & -0.33 & -0.21 & -0.29 & -0.46 & 0.43 & 0.19 & 0.23 & 0.13 & 0.38 & -0.06 & 0.32 \\
\hline & p 0.19 & p 0.64 & p 0.27 & p 0.50 & p 0.33 & p 0.12 & p 0.15 & p 0.54 & p 0.45 & p 0.67 & p 0.20 & p 0.85 & p 0.28 \\
\hline \multirow[t]{2}{*}{ Altitude } & -0.59 & 0.29 & 0.01 & -0.44 & 0.06 & 0.59 & -0.60 & -0.44 & -0.39 & -0.31 & -0.54 & -0.31 & -0.60 \\
\hline & p 0.03 & p 0.33 & p 0.98 & p 0.13 & p 0.84 & p 0.04 & p 0.03 & p 0.13 & p 0.19 & p 0.30 & p 0.06 & p 0.30 & p 0.03 \\
\hline \multirow[t]{2}{*}{ Depth } & -0.02 & -0.44 & -0.20 & 0.28 & -0.26 & -0.06 & 0.11 & -0.21 & -0.22 & -0.11 & -0.09 & 0.05 & 0.37 \\
\hline & p 0.96 & p 0.13 & p 0.51 & p 0.36 & p 0.38 & p 0.86 & p 0.73 & p 0.49 & p 0.46 & p 0.73 & p 0.77 & p 0.87 & p 0.21 \\
\hline \multirow[t]{2}{*}{ Lake area } & 0.43 & 0.67 & -0.06 & 0.41 & -0.09 & -0.33 & 0.25 & 0.45 & 0.64 & 0.74 & 0.51 & 0.16 & -0.29 \\
\hline & p 0.14 & p 0.01 & p 0.84 & p 0.16 & p 0.77 & p 0.29 & p 0.42 & p 0.12 & p 0.02 & p 0.00 & p 0.07 & p 0.60 & p 0.34 \\
\hline \multirow[t]{2}{*}{ Trasparency } & 0.06 & -0.73 & -0.50 & -0.01 & -0.48 & -0.18 & 0.25 & -0.22 & -0.29 & -0.36 & 0.00 & -0.15 & 0.52 \\
\hline & p 0.83 & p 0.01 & p 0.09 & p 0.97 & p 0.10 & p 0.55 & p 0.41 & p 0.46 & $\mathrm{p} 0.34$ & p 0.23 & p 0.99 & p 0.63 & p 0.07 \\
\hline
\end{tabular}

these lakes receive untreated sewage waters from the urban areas. For instance, slightly increased concentration of TP within lake Nahuel Huapi has been attributed to anthropogenic influences from the town of Bariloche (Markert et al. 1997). It must be also pointed out that Lake Angostura is a temporary lake, so that other variables like the hydroperiod could play a role in water chemistry. Despite its remote location, Lake Verde is mesotrophic. This can be explained by its limited area and depth and by the fact that it is a closed lake, without any inlets or outlets. It only receives meltwaters during the summer from the surrounding mountains. The biological study performed on this lake by Zagarese et al. (2000) confirmed its mesotrophic status; Lake Verde differed from the mountain lakes in the same area showing biological communities typical of low altitude lakes (Zagarese et al. 2000).

The highest TN levels $\left(>0.20 \mathrm{mg} \mathrm{N} \mathrm{L}^{-1}\right)$ are found in lakes Angostura and Verde, and also in lakes Escondido, Morenito and Trebol, which are directly impacted by the population of the city of Bariloche. All these lakes show a high development of macrophytes and submerged vegetation, that increasingly have grown during the last 10 years. Nitrate is almost absent in lake water, due to the low contribution from atmospheric deposition (Pedrozo et al. 1993). Diaz et al. (2007) suggested that this $\mathrm{N}$ poverty in lake water can be explained by deficiencies in the leachates from highly eroded lowsoluble rocks, and by the presence of a mature forest cover lack being effective in $\mathrm{N}$ uptake and retention.

Only two lakes, Gallinas and Patos, show detectable $\mathrm{NO}_{3}$ concentrations. Both are located on the Chilean border (Fig. 1), in an area where the Valdivian rain forest is the dominating vegetation. Lower rates of $\mathrm{N}$ retention in these two lake catchments could be related to an effect of the different vegetation cover; this pattern could be as well attributed to a higher rate of organic nitrogen production in vegetated catchments of the Valdivian rainforest, subsequent higher microbial nitrogen turnover and nitrate leaching from catchments into lakes. Ammonium concentrations are also very low in all the lakes $\left(1-3 \mu \mathrm{eq} \mathrm{L}^{-1}\right)$, so that the $\mathrm{N}$ in lake waters is mainly organic, representing on average $85 \%$ of the TN content.

Being the present study limited to a survey of the lake chemical characteristics, a thorough analysis of the nutrient status of the lakes is not possible. The spot sampling (one sample per each lake) also prevents us from an affordable evaluation of the N:P ratios. Previous studies pointed to a nitrogen-regulated trophic state of Patagonian lakes: Pedrozo et al. (1993) analysed nutrient concentrations in 20 lakes (including 8 of the lakes of the present study) and found $\mathrm{N}$ limitation according to the Redfield's ratio in most of the lakes. Also Diaz et al. (2007), studying chemical composition and nutrient concentrations of 39 Patagonian lakes, showed that dissolved IN is decisive in regulating the biomass carrying capacity of these ecosystems.

Results of the correlation analysis (Tab. 2) show that water chemistry was not strongly dependent on the location of the lake. Their acidic status is somewhat related to latitude and altitude. At higher altitudes, $\mathrm{pH}$, $\mathrm{Ca}^{++}$and alkalinity decrease, and the opposite occurs at lower latitudes. The former relationship may be ascribed to lower weathering rates with increasing elevation, as confirmed by the negative correlation with $\mathrm{SO}_{4}{ }^{=}$, $\mathrm{RSi}$ and alkalinity. The higher $\mathrm{Ca}^{++}$and alkalinity content in southern lakes (e.g., Huala Hue, Lezama and Epuyen) may be related to the geological features of the area.

Water transparency was inversely related to the nutrient content of the lakes, especially to TP concentrations. Some relationships between the lake area and $\mathrm{TP}$, and between lake area and some solutes $\left(\mathrm{Mg}^{++}, \mathrm{Na}^{+}\right.$, $\mathrm{K}^{+}$, alkalinity) have been also found (Tab. 2). However, this correlation was mainly driven by Lake Lezama, which is much bigger compared to the other lakes which also show quite high concentrations of the above mentioned compounds (Tab. 1).

The cluster analysis identified two main groups of lakes (Fig. 2). Both clusters I and II can be further divided into two subgroups at a linkage distance of 2.0: IA and IB and IIA and IIB, respectively. Lakes in clus- 


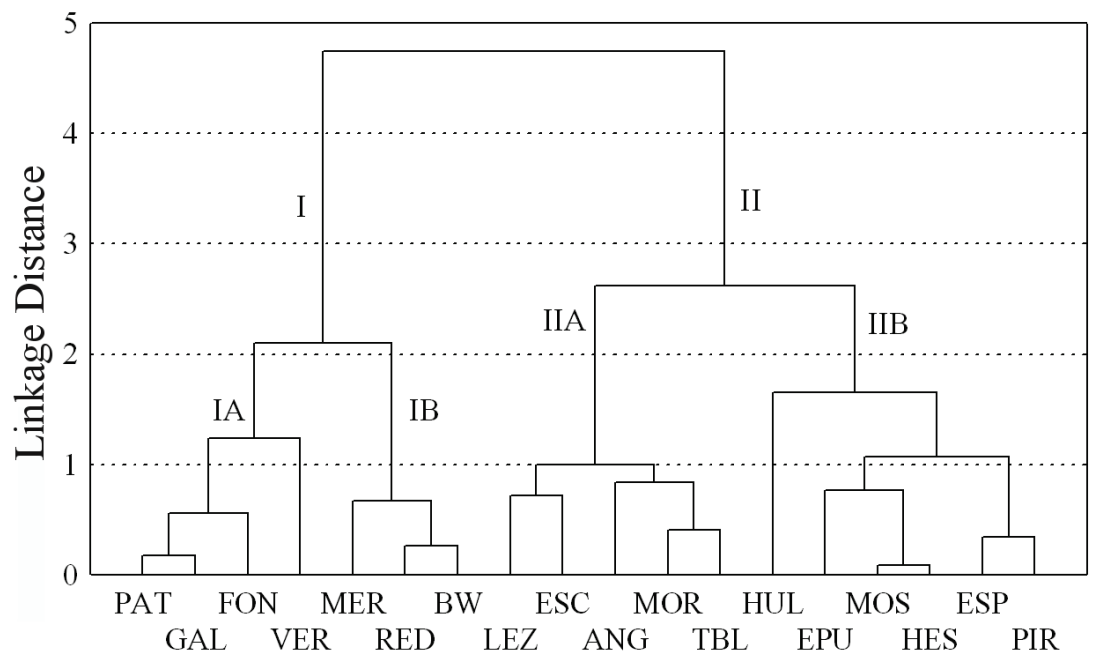

Fig. 2. Results of the cluster analysis (Ward's method, Euclidean distance) applied to chemical data (conductivity values and major ion concentrations). Lake code as in table 1.

ter I are the most dilute, showing lower conductivity values and ionic content $\left(38 \mu \mathrm{S} \mathrm{cm}^{-1}\right.$ and $860 \mu \mathrm{eq} \mathrm{L} \mathrm{L}^{-1}$ as mean values) with respect to lakes in cluster II $(61 \mu \mathrm{S}$ $\mathrm{cm}^{-1}$ and $1380 \mu \mathrm{eq} \mathrm{L}^{-1}$ ). Lakes in group I also have lower $\mathrm{pH}$ values and $\mathrm{SO}_{4}{ }^{=}$concentrations $\left(5 \mu \mathrm{eq} \mathrm{L}^{-1}\right.$, with respect to $50-55 \mu \mathrm{eq} \mathrm{L^{-1 }}$ of group II). Lakes in the subgroups IA and IB mainly differ for nutrient (TP, TN and $\mathrm{RSi}$ ) and $\mathrm{Ca}^{++}$and alkalinity concentrations, which are higher in the latter group. The highest conductivity and ionic content are found in lakes of cluster IIA (75 $\mu \mathrm{S} \mathrm{cm}^{-1}$ and $1860 \mu \mathrm{eq} \mathrm{L}^{-1}$, respectively), which also show the highest $\mathrm{TN}$ content $\left(0.27 \mathrm{mg} \mathrm{N} \mathrm{L}^{-1}\right.$ as mean value). Lakes in cluster IIB are characterised by a medium solute content, with $\mathrm{Ca}^{++}$and $\mathrm{SO}_{4}{ }^{*}$ concentration similar to those in group IIA but lower $\mathrm{Mg}^{++}, \mathrm{Na}^{+}, \mathrm{K}^{+}$ and $\mathrm{Cl}^{-}$concentrations.

Some lakes, despite they are located in the same area, belong to different chemical groups. This, highlights the role of local vegetation cover and watershed lithological composition influencing the lake water chemistry. As an example, Lakes Lezama and Epuyen, located in the southernmost part of the study area (Fig. $1)$, sharply differ regarding the ionic composition. The former, contains markedly higher concentration of $\mathrm{Mg}^{++}, \mathrm{Na}^{+}$, alkalinity, and $\mathrm{Cl}^{-}$, while the latter is richer in $\mathrm{Ca}^{++}$and $\mathrm{SO}_{4}{ }^{2}$.

In the southern part of NHNP, Lakes Fonck, Hess and Moscos are located along the course of the Rio Manso (Fig 1). However, only two of them (Lake Hess and Moscos) receive melting water from the Tronador glacier. Indeed, Lake Fonck shows a different water chemistry with a lower solute content and especially lower $\mathrm{SO}_{4}{ }^{=}$concentration than Lakes Hess and Moscos. As already pointed out by Pedrozo et al. (1993) the large debris load of the Manso Glacier derives from Monte Tronador, which lithology mainly consists of basalts, base andesites and pyroclastic breccias. The sulphate signal in Lakes Hess and Moscos, and also in Lake Hula Hue, could be attributed to weathering of these materials.

\subsection{Nitrogen content of remote lakes}

The lake TN level and the relative contribution of IN and ON was compared from 126 lakes belonging to six different groups, including the Patagonian lakes of the present study. The main characteristics of lake groups, including $\mathrm{N}$ deposition according to the available data, are summarised in table 3. Box and whiskers plots in figure 3 show the concentrations of the different forms of $\mathrm{N}$ in each lake group, while the relative contribution of IN and ON to the TN content is shown in figure 4.

The highest mean TN content was found in Antarctic lakes, where the concentrations ranged between 0.06 and $1.10 \mathrm{mg} \mathrm{N} \mathrm{L}^{-1}$ and a median value of $0.41 \mathrm{mg} \mathrm{N} \mathrm{L}^{-1}$. Several of these lakes are under the influence of marine birds and mammals; the highest TN levels ( $>1.0 \mathrm{mg} \mathrm{N}$ $\mathrm{L}^{-1}$ ) were indeed found in lakes at Edmonson Point and Inexpressible Land, located near penguin or other birds nesting (Borghini et al. 2008).

TN levels were also quite high in high altitude lakes sampled in the Central Italian Alps (median value 0.32 $\mathrm{mg} \mathrm{N} \mathrm{L}{ }^{-1}$, range $0.17-0.63 \mathrm{mg} \mathrm{N} \mathrm{L}^{-1}$ ). For these lakes $\mathrm{NO}_{3}$ represents up to $70 \%$ of the total $\mathrm{N}$ content. Lakes in the Serra da Estrela showed TN concentrations comparable to those in the Alps ( 0.24 and $0.32 \mathrm{mg} \mathrm{N} \mathrm{L}^{-1}$ as median and mean value, respectively), but with a major contribution from ON, representing almost $90 \%$ of TN (Figs 3-4). Lakes in the Svalbard Islands showed the lowest TN concentrations, between 0.03 and 0.10 mg N L ${ }^{-1}$. IN dominates in two lakes (67 and $74 \%$ of total $\mathrm{N}$, respectively) while in the third one $\mathrm{ON}$ is prevalent $(84 \%$ of $\mathrm{TN})$. 
Tab. 3. Main characteristics of the remote lakes groups considered in the present study. Altitude, conductivity and total nitrogen (TN) concentrations: mean values.

\begin{tabular}{|c|c|c|c|c|c|c|c|}
\hline Acronym & Region & n. & $\begin{array}{c}\text { Alt. } \\
\text { m a.s.1. }\end{array}$ & $\begin{array}{c}\text { Cond. } \\
\mu \mathrm{S} \mathrm{cm}^{-1} 20^{\circ} \mathrm{C}\end{array}$ & $\begin{array}{c}\mathrm{TN} \\
\mathrm{mg} \mathrm{L}^{-1}\end{array}$ & $\begin{array}{l}\text { N deposition } \\
\mathrm{kg} \mathrm{N} \mathrm{ha}^{-1} \mathrm{y}^{-1}\end{array}$ & \\
\hline AND & Andes (Northern Patagonia) & 18 & 844 & 52 & 0.17 & $0.1-0.7$ & Pedrozo et al. 1993 \\
\hline SVA & Svalbard Islands, Norway & 3 & 50 & 268 & 0.12 & $2-3$ & Beine et al. 1996 \\
\hline HIM & Himalaya (Khumbu-Himal region, Nepal) & 31 & 4941 & 29 & 0.24 & 0.3 & Tartari et al. 1998 \\
\hline ALP & Central Southern Alps, Italy & 35 & 2209 & 31 & 0.34 & $14-16$ & Rogora et al. 2006 \\
\hline ANT & Antarctica (Terra Nova Bay, Victoria Land & 29 & 59 & 1878 & 0.49 & $<0.1$ & unpublished data \\
\hline POR & Serra da Estrela, Portugal. & 9 & 1607 & 11 & 0.22 & $1.5-7$ & unpublished data \\
\hline
\end{tabular}
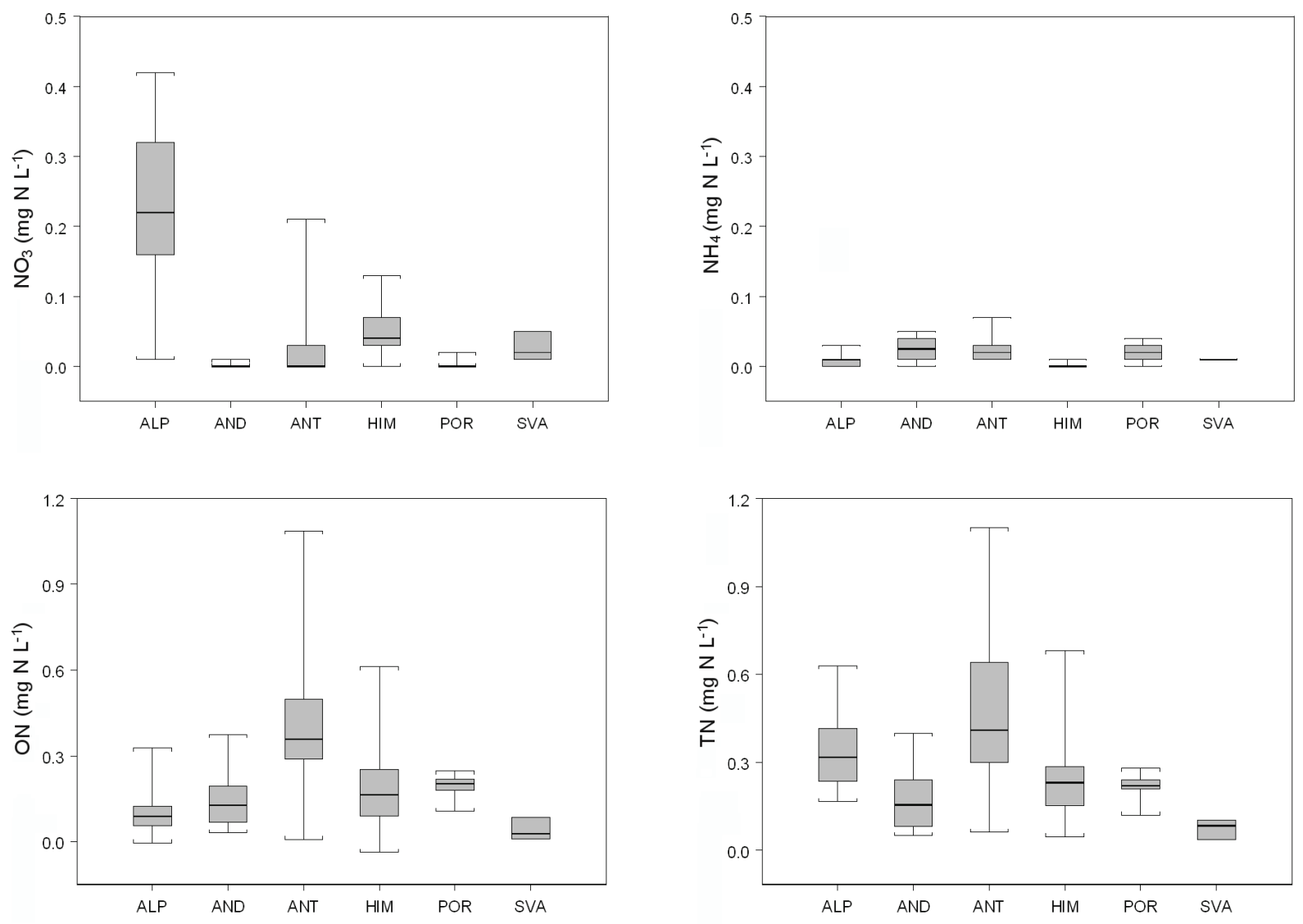

Fig. 3. Concentrations of nitric $\left(\mathrm{NO}_{3}^{-}\right)$, ammonic $\left(\mathrm{NH}_{4}^{+}\right)$, organic $(\mathrm{ON})$ and total $(\mathrm{TN})$ nitrogen in six groups of remote lakes. Whiskers: minimum and maximum values. Boxes: 25 and 75 percentiles. Thick horizontal line: median value. Acronyms as in table 3 .

Only 3 lakes in the Svallbard Islands were considered here; nevertheless, a study published elsewhere showed that their water chemistry can be considered representative for the whole area regarding lake $\mathrm{N}$ status. Indeed, stream and lake-water values for both N$\mathrm{NO}_{3}$ and N-NH$H_{4}$ for 162 localities throughout Svalbard proved to be around $0.08-0.10 \mathrm{mg} \mathrm{N} \mathrm{L}{ }^{-1}$ (Lien et al. 1995).

Most of the lakes showed ammonium concentrations close to the detection limit of the method used $(0.005$

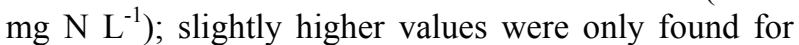
some lakes in the Andes, Antarctica and Portugal (0.05$0.07 \mathrm{mg} \mathrm{N} \mathrm{L}^{-1}$ ).
ON dominated in the Andes, Himalaya and Antarctica lakes, representing about $80 \%$ of the TN content of lake water. Mean $\mathrm{NO}_{3}$ concentrations were extremely low at these sites (usually below $0.05 \mathrm{mg} \mathrm{N} \mathrm{L}^{-1}$ ), with the exception of a few sites in Antarctica (0.10-0.20 mg $\mathrm{N} \mathrm{L}^{-1}$ as nitric $\mathrm{N}$ ). A contribution from weathering was suggested by Guilizzoni et al. (1992) to explain these anomalously high $\mathrm{NO}_{3}$ concentrations in a few Antarctic lakes in the Tarn Flat area. Borghini et al. (2008), in a survey of 28 lakes in ice-free areas of Victoria Land, also found the highest $\mathrm{NO}_{3}$ concentration in lakes at Tarn Flat. They suggested increased $\mathrm{N}$ deposition in inland ice-free areas, reduced development of cyano- 
bacterial mats, and high concentration of $\mathrm{NO}_{3}$ in some surface soils at high elevation as the possible causes for these anomalously high $\mathrm{NO}_{3}$ levels (Borghini et al. 2008). Contribution from allochtonous sources such as mammals and marine birds cannot be excluded, but this hypothesis was not supported by the very low TP concentrations in these lakes $\left(<5 \mu \mathrm{g} \mathrm{L}^{-1}\right.$; Guilizzoni et al. 1992).

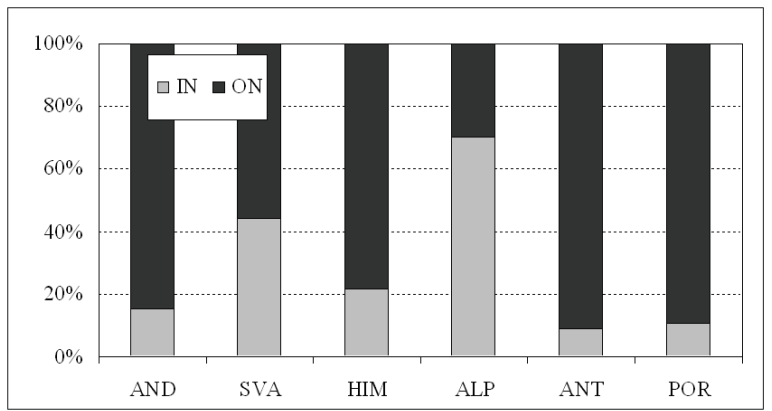

Fig. 4. Relative contribution of inorganic (IN) and organic (ON) nitrogen to the $\mathrm{TN}$ content for different remote lake groups. Acronyms as in table 3.

Numerous studies confirmed the long-range transport of air-borne pollutants from intensively cultivated or industrialised areas as the main source of $\mathrm{N}$ compounds for lakes in different remote areas of Europe, such as the upland regions of UK, the Tatra Mountians, and Fennoscandia (e.g., Allott et al. 1995; Kopacek et al. 2001; Evans et al. 2001; Wright et al. 2005). High altitude lakes in the Alps in particular, are affected by high loads of airborne pollutants coming from the South, mainly from the Po Valley, one of the most urbanised and industrialised regions of Europe. It has been also shown that atmospheric deposition contributes for almost all the $\mathrm{N}$ content of Alpine lakes, being not affected by any contribution from urban sewage or agricultural practices (Rogora et al. 2003).

This does not hold for the other remote European areas considered in this study, the Serra da Estrela and the Svalbard Island, due to the absence of relevant emission sources along the main trajectories of the air masses reaching these regions.

The chemical analysis of atmospheric deposition collected in the sampling station of Castelo Branco, in the Serra da Estrela region, showed lower concentrations of IN (from 0.07 to $0.35 \mathrm{mg} \mathrm{N} \mathrm{L}^{-1}$ as the sum of ammonium and nitrate) with respect to the values commonly found for the Alps $\left(0.8-1.0 \mathrm{mg} \mathrm{N} \mathrm{L}^{-1}\right)$. Considering an average precipitation amount of $2000 \mathrm{~mm}, \mathrm{~N}$ deposition in the Serra da Estrela should vary between 1.5 and $7.0 \mathrm{~kg} \mathrm{~N} \mathrm{ha}^{-1} \mathrm{y}^{-1}$, compared to about $15 \mathrm{~kg} \mathrm{~N}$ $h^{-1} \mathrm{y}^{-1}$ in the Alpine area (Tab. 3).

The Svalbard Islands cannot be considered a truly pristine area since they are influenced by atmospheric contaminants, especially in winter, when they are heavily loaded with a variety of anthropogenic pollutants com- ing from the industrialised areas of Central Europe, Scandinavia and North-Western Russia (Simões \& Zagorodnov 2001). However, N compounds accounted for about $10 \%$ of the atmospheric contaminants on the Svalbards, with respect to $90 \%$ represented by sulphur compounds (Lien et al. 1995). The available information on $\mathrm{N}$ deposition in high latitude regions of Europe, like Scandinavia and Greenland, as well as the data on the deposition of $\mathrm{N}$ compounds measured near $\mathrm{Ny}-$ Alesund, in the last 20 years (Beine et al. 1996), pointed out to low deposition values, close to $2-3 \mathrm{~kg} \mathrm{~N} \mathrm{ha}^{-1} \mathrm{y}^{-1}$. Also from palaeolimnological records there was no evidence for any impacts or responses resulting from atmospheric deposition of nutrients, such as $\mathrm{N}$ (Birks et al. 2004).

The remote locations outside Europe considered here, namely the Himalaya, the Andes and the Antarctica peninsula, seemed to be weakly impacted by the deposition of $\mathrm{N}$ compounds. TN levels in the lakes were low and $\mathrm{N}$ was mainly in organic form at these sites, suggesting catchment processes as the main inputs of $\mathrm{N}$ to the lakes. This was also confirmed by the available data on $\mathrm{N}$ deposition in these regions (Tab. 3).

The chemistry of atmospheric deposition in the Khumbu Himal region was investigated in 1991-1997 in the framework of the Ev-K2-CNR Project and IN concentration and deposition were below $0.07 \mathrm{mg} \mathrm{N} \mathrm{L}^{-1}$ and $0.3 \mathrm{~kg} \mathrm{~N} \mathrm{ha}^{-1} \mathrm{y}^{-1}$, respectively (Tab. 3; Tartari et al. 1998).

Pedrozo et al. (1993) analysed rainfall chemistry in the area of the Upper Manso River basin, where some of the lakes of the present study were located, and found IN concentrations below $0.03 \mathrm{mg} \mathrm{N} \mathrm{L}^{-1}$. Assuming this value as a mean concentration for Northern Patagonia, the IN input to the lake should vary between less than $0.1 \mathrm{~kg} \mathrm{~N} \mathrm{ha}^{-1} \mathrm{y}^{-1}$ in the Nahuel Huapi region to $c a 0.7 \mathrm{~kg}$ $\mathrm{N} \mathrm{ha}^{-1} \mathrm{y}^{-1}$ along the Argentina/Chilean border, in relation to precipitation amount.

Snow samples from Terra Nova Bay were analysed in the course of the 1988-89 campaign in Antarctica showing an average concentrations of $0.03 \mathrm{mg} \mathrm{N} \mathrm{L}^{-1}$ were found for both $\mathrm{N}-\mathrm{NH}_{4}$ and $\mathrm{N}-\mathrm{NO}_{3}$. Precipitation amount in the lake area is usually in the form of snow and it has been estimated to be about $200 \mathrm{~mm}$ water equivalent at the coast, and even less inland (Bull 1971), so that $\mathrm{N}$ deposition is probably below $0.1 \mathrm{~kg} \mathrm{~N} \mathrm{ha}^{-1} \mathrm{y}^{-1}$ (Tab. 3).

These data confirmed the negligible contribution of atmospheric $\mathrm{N}$ deposition in studied lakes of the Himalaya, the Andes and Antarctica regions. Also for the remote lakes in the Serra da Estrela in Portugal, and in the Svalbard Island, atmospheric deposition plays a minor role in the $\mathrm{N}$ input to lake water. The deposited $\mathrm{N}$ at these sites is entirely consumed by vegetation and micro-organisms, both in lake water and in the soil of the catchments, so that concentrations in lake water are usually very low. On the contrary, biological processes 
are not able to retain all the incoming $\mathrm{N}$ at Alpine lakes, which are subject to high level of $\mathrm{N}$ deposition. At these locations, the $\mathrm{N}$ load from the atmosphere represents the main, if not the only source of $\mathrm{N}$ to the lakes.

The Andes, Antarctica, and the Himalaya can be considered as still pristine regions from the point of view of anthropogenic $\mathrm{N}$ inputs and atmospheric pollution in general. Nevertheless, regional $\mathrm{N}$ budgets as those provided by Galloway et al. (2004) showed that human activities increasingly dominate the $\mathrm{N}$ budget at the global and at most regional scales and the fixed forms of $\mathrm{N}$ are accumulating in most environmental reservoirs also in remote areas. Asia is foreseen to have the largest increase in $\mathrm{N}$ emission and deposition by 2050 , and similar changes are predicted for Central and South America (Galloway et al. 2004).

Using output from global chemistry transport models, Phoenix et al. (2006) estimated future rates and distributions of $\mathrm{N}$ deposition within biodiversity hotspots, showing that the average deposition rate across these areas could more than double by 2050 with respect to 1990s. Among these hotspots, for Himalaya it is estimated that the percent area receiving greater than $10 \mathrm{~kg}$ $\mathrm{N} \mathrm{ha}^{-1} \mathrm{y}^{-1}$ in the 2050 will be 10 times that of 1990 (Phoenix et al. 2006). It must be highlighted that $10 \mathrm{~kg}$ $\mathrm{N}$ ha ${ }^{-1} \mathrm{y}^{-1}$ has been indicated as a critical threshold above which elevated concentrations of $\mathrm{NO}_{3}$ in surface waters may occur (Dise \& Wright 1995).

\section{CONCLUSIONS}

The new data presented in this paper about water chemistry of Patagonian lakes were consistent with that presented in previous studies (Pedrozo et al. 1993; Diaz et al. 2007). Oligotrophy was confirmed as the dominant trophic state of the lakes. Though, a few lakes, namely Redonda, Angostura and Verde, showed mesotrophic conditions, due to the location in proximity of urban areas or to morphological characteristics such as limited area and depth.

Water chemistry of the lakes is not dependent on geographical attributes but mainly governed by watershed characteristics, such as lithology. The weathering of calcium- and magnesium-carbonate proved to be the dominant process affecting lake chemistry. Pyrite oxidation was also important as a source of sulphate to a few lakes.

Patagonian lakes are characterised by extremely low values of $\mathrm{N}$ compounds; $\mathrm{NO}_{3}$ in particular is below the detection limit in most of the lakes. The comparison of Patagonian lakes with similar remote sites in the Alps demonstrated that a further explanation for the low $\mathrm{N}$ levels in the former is the negligible contribution from atmospheric sources. On the other hand, the elevate $\mathrm{NO}_{3}$ concentrations in the high altitude lakes of the European Alps is a direct effect of the high atmospheric $\mathrm{N}$ inputs affecting this area (Rogora et al. 2006). The atmospheric signal is also evident in the dominating form of $\mathrm{N}$ in lake water: $\mathrm{NO}_{3}$ is predominant in the Alps, while organic $\mathrm{N}$ is the main form in Patagonian lakes.

Additional data from remote locations throughout the world were considered to get an insight into the $\mathrm{N}$ levels of lakes in pristine areas. The results confirmed the critical situation of the Alps with respect to anthropogenic $\mathrm{N}$ inputs from downwind sources. On the contrary, the other remote European areas considered in this study were not affected by long-range transported N, due to the absence of relevant emission sources along the main trajectories of the air masses.

Overall, $\mathrm{N}$ deposition to sensitive areas may exacerbate significantly the global threat of anthropogenic pollution to water quality and biodiversity. This, highlights the relevance of regional limnological studies in remote areas and the need for a global approach to assess the impacts of $\mathrm{N}$ deposition.

\section{ACKNOWLEDGMENTS}

Fieldwork in the Andes region was coordinated and carried out by Julieta Massaferro from INIBIOMA/ CONICET with the invaluable help of Andrea Rizzo from $\mathrm{CAB} / \mathrm{CNEA}$, Bariloche, Argentina. The original study was part of the Doctoral Thesis of Sarah Gilchrist (Gilchrist, unpublished) which project sponsored the fieldwork.

Data collection in Central Alps, Italy, the Svalbard Islands, the Khumbu-Himal region, Nepal, and the Terra Nova Bay, Antarctica, was partly supported by the EU projects RECOVER: 2010 (Project N. EVK1-99-00087) and EMERGE (Project No. EVK1-1999-00159), the CNR POLARNET Strategic Programme, and grants from ENEA and CNR in the framework of the "National Program of Scientific Research in Antarctica", respectively.

\section{REFERENCES}

Allan, R.J. 1999. Atmospheric mercury contamination of remote aquatic ecosystems in Canada. Water Sci. Technol., 39: $173-177$.

Allott, T.E.H., C.J. Curtis, J. Hall, R. Harriman \& R.W. Battarbee. 1995. The impact of nitrogen deposition on upland surface waters in Great Britain: A regional assessment of nitrate leaching. Water Air Soil Poll., 85: 297-302.

Ariztegui, D., M.M. Bianchi, J. Masaferro, E. Lafargue \& F. Niessen. 1998. Interhemispheric synchrony of Late-glacial climatic instability as recorded in proglacial Lake Mascardi, Argentina. J. Quaternary Sci., 12: 333-338.

Balseiro, E.G., B.E. Modenutti \& C.P. Queimalinos. 1997. Nutrient recycling and shifts in N:P ratio by different zooplankton structures in a South Andes lake. J. Plankton Res., 19: 805-817.

Balseiro, E.G., B.E. Modenutti \& C.P. Queimalinos. 2001. Feeding of Boeckella gracilipes (Copepoda, Calanoida) on ciliates and phytoflagellates in an ultraoligotrophic Andean lake. J. Plankton Res., 23: 849-857.

Baron, J.S. \& N. Caine. 2000. The temporal coherence of two alpine lake basins of the Colorado Front Range, U.S.A. Freshwat. Biol., 43: 463-476.

Battarbee, R.W., J. Grytnes, R. Thompson, P.G. Appleby, J. Catalan, A. Korhola, H.J.B. Birks, E. Heegaard \& A. Lami. 2002. Comparing palaeolimnological and instru- 
mental evidence of climate change for remote mountain lakes over the last 200 years. J. Paleolimnol., 28: 161-179.

Beine, H.J., M. Engardt, D.A. Jaffe, Ø. Hov, K. Holmen \& F. Stordal. 1996. Measurements of NOx and aerosol particles at the Ny-Alesund Zeppelin mountain station on Svalbard; influence of regional and local pollution sources. Atmos. Environ., 30: 1067-1079.

Birks, H.J.B., V.J. Jones \& N.L. Rose. 2004. Recent environmental change and atmospheric contamination on Svalbard as recorded in lake sediments - synthesis and general conclusions. J. Paleolimnol., 31: 531-546.

Boavida, M.J. \& Z.M. Gliwicz. 1996. Limnological and biological characteristics of the alpine lakes of Portugal. Limnetica, 12, 39-45.

Borghini, F., A. Colacevich, T. Caruso \& R. Bargagli. 2008. Temporal variation in the water chemistry of northern Victoria Land lakes. Aquat. Sci. DOI 10.1007/s00027-0088026-0 (on-line version available)

Bull, C. 1971. Snow accumulation in Antarctica. In: L.O. Quam (Ed.), Research in the Antarctic. American Association for the Advancement of Science, Publication 93, Washington, DC: 367-424.

Callieri, C., B. Modenutti, C. Queimaliños, R. Bertoni \& E. Balseiro. 2007. Production and biomass of picophytoplankton and larger autotrophs in Andean ultraoligotrophic lakes: differences in light harvesting efficiency in deep layers. Aquat. Ecol., 41: 511-523.

Campos, H. 1984. Limnological study of Araucanian lakes (Chile). Verh. int. Ver. Limnol., 22: 1319-1327.

Carrera, G., P. Fernandez, J.O. Grimalt, M. Ventura, L. Camarero, J. Catalan, U. Nickus, H. Thies \& R. Psenner. 2002. Atmospheric deposition of organochlorine compounds to remote high mountain lakes of Europe. Environ. Sci. Technol., 36: 2581-8.

Catalan, J., S. Pla, M. Rieradevall, M. Felip, M. Ventura, T. Buchaca, L. Camarero, A. Brancelj, P. G. Appleby, A. Lami, J.A. Grytnes, A. Agustí-Panareda \& R. Thompson. 2002. Lake Redó ecosystem response to an increasing warming in the Pyrenees during the twentieth century. $J$. Paleolimnol., 28: 129-145.

Curtis, C.J., I. Botev, L. Camarero, J. Catalan, D. Cogalniceanu, M. Hughes, M. Kernan, J. Kopáček, A. Korhola, R. Mosello, R. Psenner, M. Rogora, E. Stuchlík, M. Veronesi \& R. Wright. 2005. Acidification in European mountain lake districts: a regional assessment of critical load exceedances. Aquat. Sci., 67: 237-251.

Diaz, M., F. Pedrozo, C. Reynolds \& P. Temporetti. 2007. Chemical composition and the nitrogen-regulated trophic state of Patagonian lakes. Limnologica, 37, 17-27.

Dise, N.B. \& R.F. Wright. 1995. Nitrogen leaching in European forests in relation to nitrogen deposition. Forest Ecol. Manag., 71: 153-162.

Drago, E. \& R. Quiros. 1995. The hydrochemistry of the inland waters of Argentina: a review. Int. J. Salt Lake Res., 4: 315-325.

Evans, C.D., J.M. Cullen, C. Alewell, J. Kopáček, A. Marchetto, F. Moldan, A. Prechtel, M. Rogora, J Veselý \& R.F. Wright. 2001. Recovery from acidification in European surface waters. Hydrol. Earth System Sci., 5: 283297.

Fernandez, C.A. (Ed.). 1994. Special Issue: Paleolimnology in Southern South America. J. Paleolimnol., 10: 68 pp.

Filippelli, G.M., C. Souch, B. Menounos, S. Slater-Atwater, T. Jull \& O. Slaymaker. 2006. Alpine lake records reveal the impact of climate and rapid climate change on the biogeochemical cycling of soil nutrients: Quaternary Res., 66: 158-166.

Galloway, J.N., F.J. Dentener, D.G. Capone, E.W. Boyer, R.W. Howarth, S.P. Seitzinger, G.P. Asner, C.C. Cleveland, P.A. Green, E.A. Holland, D.M. Karl, A.F. Michaels, J.H. Porter, A.R. Townsend \& C.J. Vörösmarty. 2004. Ni- trogen cycles: past, present, and future. Biogeochemistry, 70: $153-226$

Guilizzoni, P., V. Libera, M. Manca, R. Mosello, D. Ruggiu \& G.A. Tartari. 1992. Preliminary results of limnological research in Terra Nova Bay area (Antarctica). In. Mosello, R., B.M. Wathne, G. Giussani (Eds), Limnology on groups of remote lakes: ongoing and planned activities. Documenta Ist. ital. Idrobiol., 32: 107-120.

Guilizzoni, P., A. Marchetto, A. Lami, A. Brauer, L. Vigliotti, S. Musazzi, L. Langone, M. Manca, F. Lucchini, N. Calanchi, E. Dinelli \& A. Mordenti. 2006. Records of environmental and climatic changes during the late Holocene from Svalbard: palaeolimnology of Kongressvatnet. $J$. Paleolimnol., 36: 325-351.

Hedin, L.O., J.J. Armesto \& A.H. Johnson. 1995. Patterns of nutrient loss from unpolluted, old-growth temperate forests: Evaluation of biogeochemical theory. Ecology, 76: 493-509.

Heit, M., C. Klusek \& J. Baron. 2004. Evidence of deposition of anthropogenic pollutants in remote rocky mountain lakes. Water Air Soil Poll., 22: 403-416.

Kaushal, S.S. \& W.M. Lewis Jr. 2003. Patterns in the chemical fractionation of organic nitrogen in Rocky Mountain streams. Ecosystems, 6: 483-492.

Kopácek, J., J. Veselý \& E. Stuchlík. 2001. Sulphur and nitrogen fluxes and budgets in the Bohemian Forest and Tatra Mountains during the Industrial Revolution (1850-2000). Hydrol. Earth Syst. Sci., 5, 391-406.

Kumke, T., M. Ksenofontova, L. Pestryakova, L. Nazarova \& H.W. Hubberten. 2007. Limnological characteristics of lakes in the lowlands of Central Yakutia, Russia. $J$. Limnol., 66: 40-53.

Lien, L., A. Henriksen \& T.S. Traaen. 1995. Critical loads of acidity to surface waters: Svalbard. Sci. Tot. Environ., 160/161: 703-713.

Llames, M.E. \& A. Vinocur. 2007. Phytoplankton structure and dynamics in a volcanic lake in Deception Island (South Shetland Islands, Antarctica). Polar Biol., 30: 849857.

Macek, M., C. Callieri, K. Šimek \& A. Vázquez. 2006. Seasonal dynamics, composition and feeding patterns of ciliate assemblages in oligotrophic lakes covering a wide $\mathrm{pH}$ range. Arch. Hydrobiol., 166: 261-287.

Marchetto, A., R. Mosello, G.A. Tartari, M. Bianchi, H. Geiss, G. Serrini, G. Serrini-Lanza \& H. Muntau. 1999. Performances of analytical methods for freshwater analysis assessed through intercomparison exercises. II. Major ions. J. Limnol., 58: 33-41.

Markert, B., F. Pedrozo, W. Geller, K. Friese, S. Korhammer, G. Baffico, M. Diaz \& S. Wölfl. 1997. Sci. Tot. Envir., 206: 1-15.

Massaferro, M.M., J. Massaferro, G. Roman Ross, A.J. Amos \& A. Lami. 1999. Late Pleistocene and early Holocene ecological response of Lake El Trébol (Patagonia, Argentina) to environmental changes. J. Paleolimnol., 22: 137148.

Massaferro, J. \& M. Vandergoes. 2007. Postglacial Chironomid records from Australia, New Zealand and South America. In: S.A. Elias (Ed.), Encyclopedia of Quaternary Sciences. Elsevier, MS 287: 398-409.

McGarrigle, M.L. \& W.S.T. Champ. 1999. Keeping pristine lakes clean: Loughs Conn and Mask, western Ireland. Hydrobiologia, 395: 455-469.

Modenutti, B.E., E.G. Balseiro, C.P. Queimaliños, D.A. Añon Suárez, M.C. Diéguez \& R.J. Albariño. 1998. Structure and dynamics of food webs in Andean lakes. Lakes Reservoirs: Res. Manage, 3: 179-186.

Modenutti, B., C. Queimaliños, E. Balseiro \& M. Reissig. 2003. Impact of different zooplankton structures on the microbial food web of a South Andean oligotrophic lake. Acta Oecol., 24: 289-298. 
Modenutti, B., E. Balseiro, C. Callieri, C. Queimaliños \& R. Bertoni. 2004. Increase in photosynthetic efficiency as a strategy of planktonic organisms exploiting deep lake layers. Freshwat. Biol., 49, 160-169.

Morris, D.P., H. Zagarese, C. E. Williamson, E.G. Balseiro, B.R. Hargreaves, B. Modenutti, R. Moeller \& C. Queimaliños. 1995. The attenuation of solar UV radiation in lakes and the role of dissolved organic carbon. Limnol. Oceanogr., 40(8): 1381-1391.

Paruelo, J.M., A. Beltran, E. Jobbagy, O. Sala \& N. Golluscio. 1998. The Climate of Patagonia: general patterns and control on biotic processes. Ecologia Austral, 8: 85-103.

Pedrozo, F., S. Chillrud, P. Temporetti \& M. Diaz. 1993. Chemical composition and nutrient limitation in rivers and lakes of Northern Patagonian Andes $\left(39.5^{\circ}-42^{\circ} \mathrm{S} ; 71^{\circ} \mathrm{W}\right.$ ) (Rep. Argentina). Verh. int. Ver. Limnol., 25: 207-214.

Pedrozo, F.L. \& S.N. Chillrud. 1998. Relative water fluxes and silicate weathering from the tributaries of a small glaciated watershed in the Southern Patagonian Andes (Upper manso watershed, Argentina). Verh. int. Ver. Limnol., 26: 935-939.

Perez, G., C. Queimalinos, E. Balseiro \& B. Modenutti. 2007.Phytoplankton absorption spectra along the water column in deep North Patagonian Andean lakes (Argentina). Limnologica, 37: 3-16.

Phoenix, G.K., W.K. Hicks, S. Cinderby, J.C.I. Kuylenstierna, W.D. Stock, F.J. Dentener, K.E. Giller, A.T. Austin, R.D.B. Lefroy, B.S. Gimeno, M.R. Ashmore \& P. Ineson. 2006. Atmospheric nitrogen deposition in world biodiversity hotspots: the need for a greater global perspective in assessing N deposition impacts. Global Change Biol., 12: 470-476.

Psenner, R., R. Mosello, A. Boggero, A. Marchetto \& B. Wathne. 2000. Mountain lake research (MOLAR): atmospheric deposition and lake water chemistry. Verh. int. Ver. Limnol., 27: 1008-1012.

Quirós, R. 1988. Relationships between air temperature, depth, nutrients and chlorophyll in 103 Argentinian lakes. Verh. int. Ver. Limnol., 23, 647-58.

Quirós, R. 1991. Empirical relationships between nutrients, phytoplankton and zooplankton, and relative fish biomass in lakes and reservoirs of Argentina. Verh. int. Ver. Limnol., 24: 1198-206.

Quirós, R. \& E. Drago. 1999. The environmental state of Argentinean lakes: an overview. Lakes Reservoirs: Res. Manage., 4: 55-64.

Rogora, M., R. Mosello \& S. Arisci. 2003. The effect of climate warming on the hydrochemistry of alpine lakes. Water Air Soil Poll., 148: 347-361.

Rogora, M., R. Mosello, S. Arisci, M.C. Brizzio, A. Barbieri, R. Balestrini, P. Waldner, M. Schmitt, M. Stähli, A. Thimonier, M. Kalina, H. Puxbaum, U. Nickus, E. Ulrich $\&$ A. Probst. 2006. An overview of atmospheric deposition chemistry over the Alps: present status and long-term trends. Hydrobiologia, 562: 17-40.
Rose, N.L. 1995. The carbonaceous particle record in lake sediments from the Arctic and other remote areas of the northern hemisphere. Sci. Total Environ., 160/161: 487496.

Simões, J.C. \& V.S. Zagorodnov. 2001. The record of anthropogenic pollution in snow and ice in Svalbard, Norway. Atmos. Environ., 35: 403-413.

Smol, J.P., A.P. Wolfe, H.J.B. Birks, M.S.V. Douglas, V.J. Jones, A. Korhola, R. Pienitz, K. Ruhland, S. Sorvari, D. Antoniades, S.J. Brooks, M.A. Fallu, M. Hughes, B. Keatley, T. Laing, N. Michelutti, L. Nazarova, M. Nyman, A.M. Paterson, B.B. Perren, R. Quinlan, M. Rautio, E. Saulnier-Talbot, S. Siitonen, N. Solovieva \& J. Weckstrom. 2005. Climate-driven regime shifts in the ecology of arctic lakes. Proceedings of the National Academy of Sciences, 102: 4397-4402.

Sommaruga, R. 2007. Interactions between solar ultraviolet radiation and climatic warming in alpine lakes. In: $\mathrm{R}$. Baudo, G. Tartari \& E. Vuillermoz (Eds), Mountains: Witnesses of Global Changes - Research in the Himalaya and Karakoram. Developments in Earth surface processes, Elsevier, Amsterdam, 10: 185-186.

Soto, D., H. Campos, W. Steffen, O. Parra \& L. Zuniga. 1994. The Torres del Paine lake district (Chilean Patagonia): a case of potentially N-limited lakes and ponds. Arch. Hydrobiol., Suppl. 99: 181-197.

Tartari, G.A. \& R. Mosello. 1997. Metodologie analitiche e controlli di qualità nel laboratorio chimico dell'Istituto Italiano di Idrobiologia del Consiglio Nazionale delle Ricerche. Documenta Ist. ital. Idrobiol., 60: 160 pp.

Tartari, G.A., G. Tartari \& R. Mosello. 1998. Water chemistry of high altitude lakes in the Khumbu and Imja Kola valleys (Nepalese Himalayas). In: Lami, A. \& G. Giussani (Eds), Limnology of high altitude lakes in the Mt Everest Region (Nepal). Mem. Ist. ital. Idrobiol., 57: 51-76.

Thomasson, K. 1959. Nahuel Huapi. Plankton of some lakes in an Argentine National Park. Acta Phytogr. Suecica, Uppsala, 42: 1-83.

Thomasson, K. 1963. Araucarian lakes. Plankton studies on North Patagonia. Acta Phytogr. Suecica, Uppsala, 47: 1139.

Wolfe, A.P., J.S. Baron \& R.J. Cornett. 2001. Anthropogenic nitrogen deposition induces rapid ecological changes in alpine lakes of the Colorado Front Range (USA). $J$. Paleolimnol., 25: 1-7.

Woelfl, S. (Ed.). 2007. Limnology of Temperate South America. Limnologica, 37: $120 \mathrm{pp}$.

Wright, R.F., L. Camarero, B.J. Cosby, R. C. Ferrier, M. Forsius, R. Helliwell, A. Jenkins, J. Kopacek, V. Majer, F. Moldan, M. Posch, M. Rogora \& W. Schöpp. 2005. Recovery of acidified European surface waters. Environ. Sci. Technol., 39: 64A-74A.

Zagarese, H.E., M. Diaz, F. Pedrozo \& C. Ubeda. 2000. Mountain lakes in northwestern Patagonia. Verh. int. Ver. Limnol., 27: 533-538.

Received: March 2008

Accepted: June 2008 